\title{
The West Indian College of Tropical Agriculture.
}

\author{
By Prof. J. B. FARmer, F.R.S.
}

THE opening of the West Indian College of Tropical Agriculture by His Excellency Sir Samuel Wilson, the Governor of Trinidad and Tobago, on October $x 6$, was an event not merely of local, but also of Imperial interest, for it constitutes a memorable landmark in the progress of agriculture throughout the British possessions in the tropics.

The idea of such a college in the West Indies owes its inception largely to Sir Francis Watts, Imperial Commissioner of Agriculture, and the project met with support both in the West Indies and at home by men alive to the pressing need for improved facilities for agricultural education and research in the tropics.

After much preliminary exploration of various possibilities it was finally decided that the College should be located in Trinidad, and few, if any, will now question the wisdom of this decision. The Government of Trinidad has presented a magnificent site of 85 acres, at St. Augustine, which appears ample for present and, so far as can be foreseen, for future developments also. The site lies about 7 miles east of Port of Spain and is situated just south of the Main East Road, close to the junction station for the eastern and southern branches of the railway. In the opinion of the present writer, the College has secured the finest site the island could offer. Not only is the land open and well drained, but it is sufficiently exposed to the trade wind, which blows through the greater part of the year, to ensure an agreeable and healthy climate.

Further important advantage accrues to the College from its close proximity to one of the principal experimental stations and farms under the control and management of the Trinidad Department of Agriculture, the director of which, Mr. W. G. Freeman, is also a member of the governing body of the College. Thus, not only will students be able to follow the raising of such staple tropical products as sugar, cocoa, rubber, coconuts, etc., on neighbouring estates under ordinary plantation methods and conditions, but they will be able to study the same crops grown experimentally, and under rigidly scientific control. They will also become acquainted with many other tropical products not usually grown in Trinidad itself, such as cotton, camphor, spices, and so on. Furthermore, at River Estate, another large experimental station, also under the Department of Agriculture, students will have the opportunity of studying methods of propagation and cultivation of cocoa and other plants under climatic conditions sufficiently different from those prevalent at St. Augustine as to afford valuable means of comparison. Apart from the intrinsic value, both economic and scientific, of the well-planned series of experiments at River Estate, the researches there are conducted on a really large scale, and scale is a matter of no small importance when starting out on agricultural investigations.

For the present the College is housed in a building of moderate size which was already in existence on the site. It has been suitably altered and equipped, and it will provide sufficient accommodation for a limited number of students pending the erection of the new permanent buildings which it is intended shall be commenced forthwith. Residences will also be provided for the staff, and it is hoped that hostels for students may be built if, and when, funds become available. Recreation grounds for students and staff, together with refectory, common-rooms and bathrooms, are already in existence on the site.

The future of the College is well assured. In addition to granting the site, the Government of Trinidad and Tobago have given $50,000 \mathrm{l}$. towards the cost of erection and equipment of the College, and that Government, together with the Governments of Barbados, the Leeward Islands, and the Windward Islands, are contributing an annual subvention of a half of $I$ per cent. of their revenues. The Imperial Government is also providing the sum of $15,000 l$. spread over a term of five years, on the understanding that the work of the existing Imperial Department of Agriculture in the West Indies shall be carried on by the College. The latter gains in prestige by this amalgamation, for the work of the department, begun by Sir Daniel Morris and continued by Sir Francis Watts, is widely and most deservedly appreciated throughout the West Indies. Substantial contributions have also been promised by Messrs. Fry and Messrs. Cadbury, the Empire Cotton Growers' Association, and the British Cotton Growing Association, while special mention should be made of a handsome private donation by Mr. J. W. Stephens, of Trinidad. It will be seen that the enterprise has already aroused practical interest, and this augurs well for the future.

The value to the Empire of a College so favourably situated to meet the present urgent demands for training in tropical agriculture should be sufficiently obvious to every one, and its influence will not be limited to the West Indian islands alone, but cannot fail to make itself felt over far wider areas. One may perhaps be permitted to hope that this wider interest will find an expression in returns of a practical nature.

The first year's prospectus of the College has recently been issued, and copies can be obtained from Mr. A. Aspinall at the London office of the College, I4 Trinity Square, E.C. It will be noted that the academic year has been made to conform with that of British universities, and it is a fortunate circumstance that the agricultural and climatic conditions in Trinidad happen to render such an arrangement a suitable one. The following courses and facilities for study have been provisionally arranged :

(I) Diploma course.

(2) One-year course in elementary agricultural science.

(3) Courses for agricultural officers, scientific and administrative.

(4) Post-graduate research.

The diploma course will extend over three years, and its object will be to give a thorough training in the science and practice of tropical agriculture to those students intending to become either tropical planters, investigators or experts in different branches of agricultural science or technology. These students will be required to have passed the College entrance examina-

NO. 2771 , VOL. IIO] 
tion, the standard of which is intended to be that of the matriculation examination of an English university, and evidence of having passed such a matriculation examination, or other equivalent test, may be accepted by the College in lieu of its own entrance examination.

The one-year course is intended for those who require a less extensive acquaintance with the scientific aspects of agriculture, and the standard required from such entran is will be based mainly on a satisfactory school record indicating that they are able to profit by the instruction offered.

Special facilities will be afforded to officers selected for the tropical agricultural services, whether under government or otherwise, such as should enable them to obtain (through courses planned to meet individual needs) familiarity with the applications to tropical conditions of the principles they will have already acquired in Europe or elsewhere. It is difficult to exaggerate the value and importance of such training to men of this class before they proceed to take up the duties of the posts to which they may have been appointed. Hitherto there has existed a gap, largely unbridged, between the university at home and the work that awaits the scientific officer in his district, where the conditions that embrace his problems and affect their solution are so widely different from those within the range of his previous experience. The new College enables this hiatus to be short-circuited, and it should now be possible for a man in a few months to build effectively on his previous knowledge of principles. In short, he is now in a position to obtain easily, and under exceptionally favourable conditions, just that kind of wide outlook over, and reasonably intimate familiarity with, the material and environment of his prospective problems so necessary for ultimately attacking them with good prospects of success.

Perhaps, however, a word of caution may not be out of place here. In order to secure the best type of scientific officer, whether for government or for other services, it is fundamentally important that he should have received that kind of broad and thorough scientific training which only a first-rate and well-equipped university is in a position to give. It is not contended, and it must not be expected, that the training now available for scientific officers at the West Indian Agricultural College can replace this university type of education. What it can and will do is to utilise the results of that education, and to make it of more immediate and practical value. The motto of the College, Via colendi haud facilis, emphasises the difficulty of agricultural problems, and they are not going to be best attacked unless the best means are employed in the process. The combination of the home university and the tropical college unquestionably offers the best means at present in sight.

Finally, in its provision for research students the College is pursuing an excellent course. The West Indies, with the fine botanic gardens of Trinidad and Dominica, offer unrivalled opportunities to the botanist using Trinidad as a centre, and it would be difficult to find better facilities anywhere in the tropics. The relative freedom from noxious pests, the absence of the annoyance caused by the leeches of the eastern jungles, the variety and wealth of the vegetation, together with the striking ecological character it exhibits, combine to form a mort attractive prospect for any young man who desires ti secure that indispensable acquaintance with tropical vegetation without which no botanist can be said to be fully qualified to hold one of the more important chairs in the universities at home.

But it is, after all, by its success in promoting the welfare of agriculture, and of the industries that arise directly out of it, that the College will be finally judged. In this last connexion it is well to learn that technological courses are contemplated to prepare men to take their part in manufacturing processes. Some of these, for example sugar, are already of considerable importance in the West Indies and elsewhere. The establishment of a sugar school will constitute the first step in this direction, and gifts of up-to-date plant and machinery have already been generously promised by several engineering firms in Great Britain.

It will be obvious from the foregoing sketch-necessarily but an imperfect one-that the institution is making a good start. Sir Francis Watts and the little band of professors, all of whom have made their mark in various directions, will carry with them the best wishes of every one interested in the success of the great enterprise on which they have embarked.

\section{The Flow of Steels at a Low Red Heat.}

RECENT developments in chemical engineering have called for the provision of metallic containers capable of withstanding considerable stress at high temperatures and for long periods. The investigation of the mechanical properties of steels and alloys at these temperatures has accordingly become a matter of very direct practical importance. The existing literature of the subject almost invariably consists of graphs, in which tensile test results are plotted against the temperature at which the test was made, care being taken to eliminate the disturbing, but very important, factor of time, by carrying out each test under as nearly the same conditions as possible, the duration of each test being at most a few hours, with an actual loading time of a few minutes. It cannot fairly be claimed that such information gives more than a general indication of the relative ability of different materials to meet the working conditions usually encountered by the exhaust valve of an aeroengine or the retorts, catalyst tubes, etc., of the engineer. Certainly it does not enable a designer to construct a container which can be depended upon to maintain its shape indefinitely, at super-atmospheric temperatures when in a state of stress.

To remedy this defect in existing knowledge, Mr. J. H. Dickenson, of the Research Laboratories of Messrs. Vickers, Ltd., Sheffield, has carried out an experimental investigation, and communicated his results at the September meeting of the Iron and Steel Institute. His general conclusion is, that all the steels upon which he has worked behaved very much like highly viscous fluids at temperatures well below the 